\title{
ANALISA PROBABILITAS PEMILIHAN MODA TRANSPORTASI ANTARA SEPEDA MOTOR DENGAN ANGKUTAN UMUM DI KOTA LHOKSEUMAWE
}

\author{
Herman Fithra ${ }^{1)}$ Burhanuddin ${ }^{2)}$ Fauzan ${ }^{3)}$ Cut Ayu Lizar ${ }^{4)}$ \\ Dosen Jurusan Teknik Sipil,Universitas Malikussaleh \\ email:hfithra@gmail.com ${ }^{1,2)}$ \\ Mahasiswa Jurusan Teknik Sipil,Universitas Malikussaleh \\ email:cutayulizar@ymail.com ${ }^{3)}$
}

\begin{abstract}
Abstrak
Aktivitas pergerakan dapat menyebabkan proses pemilihan moda. Politeknik Negeri Lhokseumawe sebagai pusat pendidikan yang berada pada Kota Lhokseumawe menjadi salah satu pusat pergerakan bagi Mahasiswa. Dasar penelitian ini bertujuan untuk mengamati perilaku mahasiswa pengguna sepeda motor dan mikrolet serta menganalisis apakah pemilihan moda dipengaruhi oleh perubahan biaya dan waktu perjalanan. Penelitian ini dilakukan dengan data hasil pendekatan observasi, hasil kuisioner, kajian literatur dan pengolahan data dengan program SPSS dalam menggambarkan situasi perjalanan terhadap kedua moda tersebut. Gambaran komposisi karakteristik pelaku perjalanan dari data survei, diketahui karakteristik umum pengguna dalam pemilihan moda adalah responden pengguna sepeda motor sebesar $67,21 \%$ sedangkan responden pengguna mikrolet $32,79 \%$. Berdasarkan jenis kelamin, sepeda motor lebih dipilih oleh pria sebesar $50,82 \%$ dan wanita sebesar $16,39 \%$ sedangkan mikrolet lebih dipilih oleh wanita sebesar $21,31 \%$ dan pria $11,48 \%$. Alasan pemilihan moda untuk sepeda motor adalah pertimbangan waktu sebesar $54,10 \%$ dan pertimbangan biaya sebesar $13,11 \%$ sedangkan alasan pemilihan moda untuk mikrolet adalah pertimbangan biaya sebesar $22,95 \%$ dan pertimbangan waktu $9,84 \%$. Model pemilihan moda antara sepeda motor dan mikrolet yang diperoleh $\left(\mathrm{U}_{s m}-\mathrm{U}_{m k}\right)=-0,223-0,002 \mathrm{C}-0,078 \mathrm{~T}$. Pada saat kondisi selisih atribut sama dengan nol didapatkan nilai probabilitas sepeda motor lebih besar dari probabilitas mikrolet $\left(\operatorname{Pr}_{\mathrm{sm}}>\operatorname{Pr}_{\mathrm{mk}}\right)$ untuk atribut biaya dan waktu perjalanan. Model yang diperoleh dari analisa regresi terhadap semua data mempunyai harga $\mathrm{R}^{2}$ yang paling tinggi yakni 0,22 atau $22 \%$ yaitu pengaruh kedua faktor atribut yang dipertimbangkan dan sisanya $78 \%$ dipengaruhi oleh atribut yang belum dipertimbangkan. Selain 2 atribut perjalanan yang termasuk dalam penelitian ini, beberapa atribut lain juga bisa dipertimbangkan untuk diuji, seperti faktor keamanan, kenyamanan dan faktor lain yang mempengaruhi
\end{abstract}

Kata Kunci: Pemilihan Moda, Biaya, Waktu

\section{Pendahuluan}

Kota Lhokseumawe merupakan salah satu kota yang ada di Propinsi Aceh yang mempunyai banyak aktivitas penting di bidang pendidikan, politik dan ekonomi. Di samping itu pusat pemerintahan Kabupaten Aceh Utara juga masih berada pada daerah Kota Lhokseumawe, sehingga hal tersebut juga berdampak terhadap perkembangan kehidupan masyarakat Kota Lhokseumawe.

Pada umumnya mahasiswa pada kampus Politeknik Negeri Lhokseumawe menggunakan alat transportasi untuk berpergian melakukan aktivitasnya menggunakan kendaraan pribadi seperti sepeda motor atau menggunakan moda angkutan umum mikrolet atau biasa disebut dengan labi-labi pada Provinsi Aceh. 
Untuk beberapa mahasiswa bahkan mempunyai pilihan untuk menggunakan moda transportasi sepeda motor atau mikrolet, hal ini akan menimbulkan kompetisi yang membuat mahasiswa dapat memilih moda mana yang paling tepat digunakan dalam melakukan aktivitasnya.

Berdasarkan hal tersebut akan dilakukan studi terhadap probabilitas pemilihan sepeda motor dan angkutan umum mikrolet sebagai sarana dalam melakukan perjalanan. Dengan mengetahui perilaku perjalanan yang mempengaruhi probabilitas pemilihan moda, maka akan dapat dilakukan upaya perbaikan dan peningkatan pelayanan bagi pengguna moda yang bersangkutan.

Tujuan dari penelitian ini adalah untuk mengetahui variabel identitas diri atau karakteristik pelaku perjalanan dalam hubungannya dengan terpilihnya suatu moda transportasi, menentukan suatu model pemilihan moda yang dapat menjelaskan probabilitas pelaku perjalanan dalam memilih moda transportasi antara sepeda motor dan mikrolet bila ditinjau dari segi biaya perjalanan (cost) dan waktu tempuh perjalanan (time) dan untuk mengetahui perubahan probabilitas pelaku perjalanan dalam penentuan pemilihan moda apabila dilakukan perubahan terhadap biaya dan waktu perjalanannya.

\section{Tinjauan Kepustakaan}

Pemilihan moda merupakan model terpenting dalam perencanaan dan perancangan transportasi. Hal ini disebabkan oleh peran utama dari angkutan umum dalam berbagai kebijakan transportasi (Miro, 2005).

\subsection{Penentuan jumlah sampel}

Rumus yang digunakan dalam penentuan jumlah sampel adalah sebagai berikut (walpole:1974):

$$
n=\left(\frac{Z_{\alpha} \sigma}{g}\right)^{2}
$$

di mana:

$n$ = Jumlah sampel yang dibutuhkan

$Z \alpha=$ Nilai kritis distribusi $t$ untuk tingkat keberartian $\alpha$ (level of significant)

$\sigma=$ Standar deviasi sampel dari populasi

$g=$ Galat yang dikehendaki

\subsection{Model Logit Binomial}

Pada model logit binomial pengambil keputusan dihadapkan pada sepasang alternatif diskrit, dimana alternatif yang akan dipilih adalah yang mempunyai utiliti terbesar, utiliti dalam hal ini dipandang sebagai variabel acak (random). Dalam penelitian ini pemilihan moda angkutan umum penumpang dan sepeda motor yang akan diteliti. Dengan 2 (dua) alternatif moda yang dibandingkan, adapun persamaan yang digunakan adalah:

- Probabilitas pengguna moda sepeda motor :

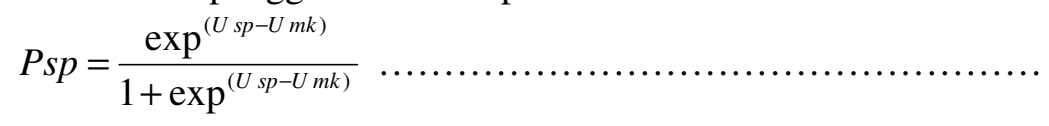

- Probabilitas pengguna Mikrolet :

Analiasa Probabilitas Pemilihan Moda Transportasi Antara Sepeda Motor Dengan Angkutan Umum di Kota Lhokseumawe - HermanFithra, Burhanuddin, Fauzan, Cut Ayu Lizar 


$$
P m k=1-\mathrm{P}_{\mathrm{sp}}
$$

di mana:

Psp = Probabilitas pemilihan moda sepeda motor

Pmk $=$ Probabilitas pemilihan moda mikrolet

Usp = Utilitas pemilihan moda sepeda motor

Umk = Utilitas pemilihan moda mikrolet

\subsection{Teknik Stated Preference}

Menurut Permain (1991), Stated Preference merupakan satu pendekatan kepada responden dalam memilih alternatif terbaiknya dengan membuat suatu alternatif. Kuisioner tersebut berisi pertanyaan mengenai pilihan apa yang mereka inginkan atau bagaimana mereka membuat rating/rangking atau pilihan tertentu dalam satu atau beberapa situasi dugaan.

\section{Identifikasi Pilihan}

Cara yang dipakai untuk mengumpulkan informasi pada preferensi dalam penelitian ini yaitu: Rating Responses (Functional Measurement). Dalam teknik ini, responden mengekspresikan derajat pilihan terbaiknya, dengan skala semantik atau numerik. Skala tersebut didefinisikan dengan kalimat seperti "pasti memilih 1", "mungkin memilih 2" atau "tidak memilih 1 atau 2 ". Responden diminta untuk mengekspresikan pilihannya terhadap masing masing pilihan dengan menunjukkan "skor " tertentu. Dalam hal ini digunakan skala 1 sampai 5 untuk menunjukkan kemungkinan pilihan. Selanjutnya skor tersebut dapat ditransfomasikan dalam bentuk probabilitas yang masuk akal dari pilihan-pilihan tersebut, misalnya skor $1=0,1$; skor $3=0,5$; skor $5=0,9$.

\section{Analisa Data Stated Preference}

Fungsi utilitas adalah mengukur daya tarik setiap pilihan (skenario hipotesa) yang diberikan pada responden. Fungsi ini merefleksikan pengaruh pilihan responden pada seluruh atribut yang termasuk dalam stated preference. Umumnya fungsi utilitas berbentuk linear, sebagai berikut:

$$
U j=a+b 1 x 1+b 2 x 2+\ldots+b n x n \ldots \ldots \ldots \ldots \ldots \ldots \ldots \ldots \ldots \ldots \ldots \ldots \ldots \ldots \ldots \ldots \ldots
$$

Di mana :

$$
\begin{array}{ll}
U j & =\text { utilitas pilihan } \mathrm{j} \\
a & =\text { konstanta regresi } \\
b 1, \ldots, b n & =\text { parameter model } \\
x 1, x 2, \ldots, x n & =\text { nilai atribut }
\end{array}
$$

Melalui langkah-langkah dalam metode regresi dengan menggunakan alat bantu komputer (Program SPSS) akan diperoleh persamaan dengan sejumlah koefisien regresi, sehingga masing-masing konstanta akan dapat diperoleh dan dianalisis.

\subsection{Uji Statistik dalam Model}

Uji statistic F pada dasarnya menunjukkan apakah semua variabel independen atau bebas yang dimasukkan dalam model mempunyai pengaruh secara bersama-sama terhadap variabel dependen atau terikat. 


\section{$3 \quad$ Metode Penelitian}

Adapun tahapan-tahapan kegiatan penelitian dalam studi ini dilakukan sebagai berikut:

1. Tahapan pertama adalah merumuskan permasalahan

Mengidentifikasi kondisi moda yang akan diteliti serta kondisi yang ada saat ini penggunaan angkutan umum dan sepeda motor

2. Tahapan kedua adalah studi literatur berupa landasan teori, metode perhitungan yang akan digunakan untuk pengolahan data atau dalam melakukan analisa.

3. Tahapan ketiga adalah merumuskan formulir survey.

4. Tahapan keempat adalah pengumpulan data

5. Tahapan kelima adalah pembahasan atau pengolahan data.

Data yang diperoleh dari hasil survei dikumpulkan dan diolah dan disajikan dalam bentuk yang lebih sederhana (persentase responden dalam memilih) sehingga memudahkan dalam pengerjaan tahap berikutnya.

6. Tahapan keenam adalah analisa data

Pada tahapan ini hasil pengolahan data dianalisa model regresinya menggunakan program SPSS. Kemudian dihitung nilai probabilitasnya dengan menggunakan model logit binomial.

7. Tahapan ketujuh adalah kesimpulan dan saran

Pada tahap ini diperoleh sebuah kesimpulan faktor yang mempengaruhi pemilihan moda transportasi dan nilai probabilitasnya.

\section{Hasil dan Pembahasan}

Survei dilakukan pada mahasiswa Politeknik Negeri Lhokseumawe dengan jumlah responden sebesar:

\section{Penentuan Jumlah Sampel}

Dari hasil survei pendahuluan terhadap 50 responden, masing-masing responden menjawab 10 option dari seluruh responden. Jumlah option responden terkumpul $=50 \times 10$

Tabel 1. Acuan menentukan jumlah sampel: probabilitas individu memilih sepeda motor atau mikrolet.

\begin{tabular}{|c|c|c|c|c|c|c|}
\hline Makna Pilihan & $\begin{array}{c}\operatorname{Pr} \\
(\text { moda }) \\
(\mathrm{p})\end{array}$ & $\begin{array}{c}\text { Jumlah } \\
\text { responden }\end{array}$ & $\begin{array}{c}\text { Jumlah } \\
\text { Option } \\
\text { Reponden (n) }\end{array}$ & n.p & $\left(\mathrm{p}-\mathrm{p}_{\text {rerata }}\right)$ & $\mathrm{n}\left(\mathrm{p}-\mathrm{p}_{\text {rerata }}\right)^{2}$ \\
\hline Pasti pilih Mikrolet & 0,1 & 4 & 40 & 4 & $-0,6$ & 16,80 \\
\hline Mungkin pilih Mikrolet & 0,3 & 3 & 30 & 9 & $-0,4$ & 6,02 \\
\hline Pilihan Berimbang & 0,5 & 2 & 20 & 10,0 & $-0,2$ & 1,23 \\
\hline Mungkin pilih Sepeda Motor & 0,7 & 9 & 90 & 63,0 & 0,0 & 0,21 \\
\hline Pasti pilih Sepeda Motor & 0,9 & 32 & 320 & 288,0 & 0,2 & 7,39 \\
\hline \multicolumn{2}{|l|}{ Jumlah total } & 50 & 500 & 374,0 & & 31,65 \\
\hline
\end{tabular}

Probabilitas rata-rata sampel, prerata $=374,0 / 500 \quad=0,7$

Variasi sampel, $\sigma^{2} \alpha=\sum \mathrm{n}\left(\mathrm{p}-\mathrm{p}_{\text {rerata }}\right)^{2} /(\mathrm{n}-1) \quad=0,063$

Standar deviasi sampel, $\sigma=\sqrt{\sum n \cdot\left(p-p_{\text {rerata }}\right)^{2} /(n-1)}=0,252$

Asumsi tingkat keberartian (level of significant), $\alpha / 2=0,05(5 \%)$ 
Maka, dari tabel normal $t$ diperoleh $\mathrm{Za} / 2$

$$
\begin{aligned}
& =1,96 \\
& =0.02 \\
& =609,11 \\
& =61
\end{aligned}
$$

Maka, jumlah sampel minimal $: \mathrm{n}=\left(\sigma \cdot Z_{\alpha} / 2 / g\right)^{2}=609,11$

Jumlah responden $\mathrm{n} / 10$

Dari nilai yang didapat, diambil sebesar 130 sampel untuk data kuisioner.

\section{Kondisi Eksisting}

Adapun kondisi eksisting dari masing-masing moda yang ditinjau baik mikrolet maupun sepeda motor dapat dilihat pada tabel berikut ini:

Tabel 2. Atribut masing-masing moda dan pelayanan secara aktual

\begin{tabular}{c|l|c|c}
\hline No & \multicolumn{1}{|c|}{ Atribut Perjalanan } & Labi-labi & Sepeda Motor \\
\hline 1 & Biaya Perjalanan & Rp2.000 & Rp1.750 \\
\hline 2 & Waktu Tempuh Perjalanan & 25 Menit & 15 Menit \\
\hline
\end{tabular}

Berikut ini adalah penjelasan dari masing-masing atribut pada moda:
a. Biaya perjalanan (cost)
b. Waktu tempuh perjalanan (time)

Dalam format kuisioner, data responden diperoleh melalui teknik rating dengan 5 poin skala semantik yaitu:

- 1 = Pasti pilih Mikrolet

- 2 = Mungkin pilih Mikrolet

- $3=$ Pilihan Berimbang

- 4 = Mungkin pilih Sepeda Motor

- 5 = Pasti pilih Sepeda Motor

\section{Pemaparan Hasil Survei}

Tabel 4. Distribusi responden pengguna sepeda motor dan mikrolet

\begin{tabular}{c|l|c|c}
\hline No & \multicolumn{1}{|c|}{ Responden Pengguna } & Jumlah & Persentase \\
\hline 1 & Sepeda Motor & 82 & 67,21 \\
\hline 2 & Mikrolet & 40 & 32,79 \\
\hline
\end{tabular}

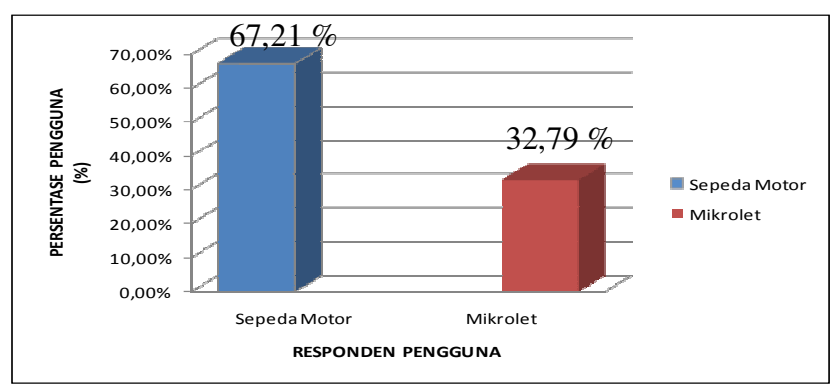

Gambar 1. Grafik distribusi responden pengguna sepeda motor dan mikrolet

Berdasarkan distribusi responden terhadap moda yang menjadi pilihannya, kemudian akan dilihat kondisi karakteristik dari pengguna untuk masing-masing jenis moda, yaitu sebagai berikut: 
a. Alasan pengguna moda

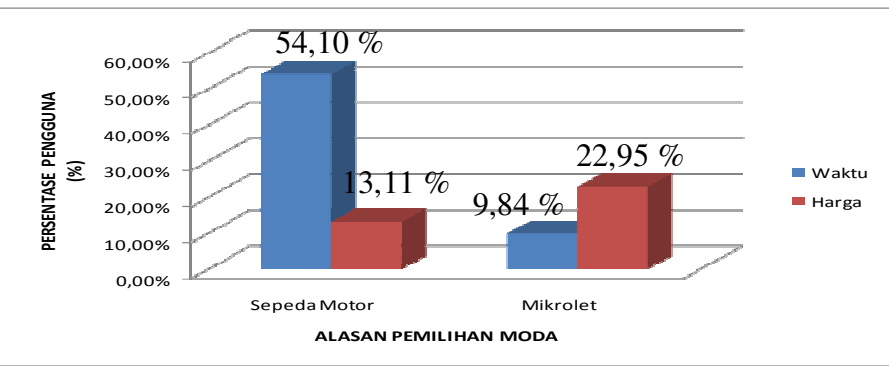

Gambar 2. Grafik distribusi alasan pengguna moda sepeda motor dan mikrolet

b. Golongan pelaku

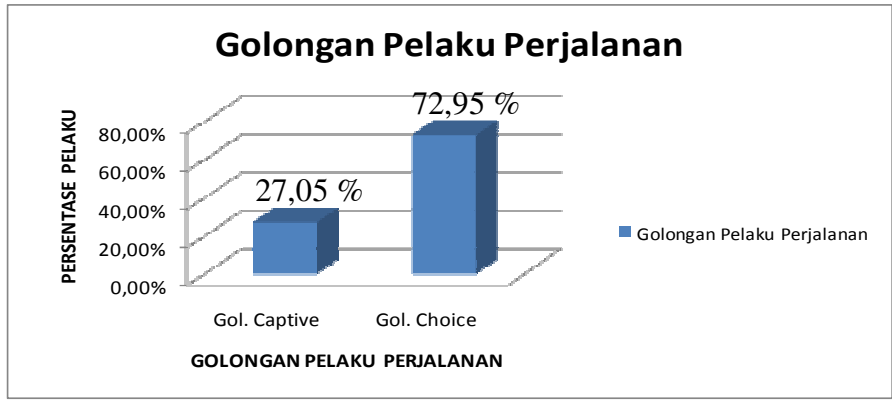

Gambar 3. Grafik distribusi golongan pelaku responden

\section{Kompilasi data}

Tabel 5. Data hasil survei kuisioner dengan teknik stated preference sepeda motor dengan mikrolet

\begin{tabular}{|c|c|c|c|c|c|}
\hline \multirow{2}{*}{$\begin{array}{c}\text { Nomor } \\
\text { Responden }\end{array}$} & \multicolumn{2}{|c|}{$\begin{array}{c}\text { Selisih Nilai Variabel } \\
\text { Bebas }\end{array}$} & \multicolumn{2}{|c|}{ Jawaban Responden } & \multirow{2}{*}{$\begin{array}{c}\text { Skala Nilai } \\
\text { Numerik }\end{array}$} \\
\hline & Cost (Rp) & Time (Menit) & Option & Point Rating & \\
\hline \multirow{10}{*}{1} & 750 & -10 & $1 \mathrm{a}$ & 1 & $-2,1972$ \\
\hline & 250 & -10 & $\mathrm{~B}$ & 2 & $-0,8473$ \\
\hline & 0 & -10 & $\mathrm{C}$ & 2 & $-0,8473$ \\
\hline & -250 & -10 & $\mathrm{D}$ & 2 & $-0,8473$ \\
\hline & -750 & -10 & $E$ & 5 & 2,1972 \\
\hline & -250 & -5 & $2 \mathrm{a}$ & 5 & 2,1972 \\
\hline & -250 & -10 & $\mathrm{~B}$ & 5 & 2,1972 \\
\hline & -250 & 0 & $\mathrm{C}$ & 5 & 2,1972 \\
\hline & -250 & 5 & $\mathrm{D}$ & 2 & $-0,8473$ \\
\hline & -250 & 10 & $E$ & 1 & $-2,1972$ \\
\hline
\end{tabular}

Nomor responden 1, dalam kondisi stated preference cost (c) didapatkan dari perubahan pada biaya atribut perjalanan yaitu selisih antara biaya sepeda motor dan mikrolet. Dapat dilihat pada kolom 1 dan 2, pada option 1.a diketahui biaya perjalanan sepeda motor dan mikrolet $1.750-1.000=750$. Sedangkan time (t) tetap pada kondisi moda saat ini yaitu selisih waktu perjalanan antara sepeda motor dan mikrolet yaitu $(15$ menit $)-(25$ menit $)=-$ 10 menit. Option 1a menunjukkan poin rating 1 ( pasti memilih mikrolet) dengan nilai skala numerik berdasarkan pengguna moda sebesar 2,1972. 
Pada option 2.a time (t) dalam kondisi stated preference, sedangkan cost (c) tetap pada kondisi moda saat ini. Cara menghitung sama seperti option 1.a.

Begitu seterusnya sampai responden no 122 responden yang memenuhi syarat, kemudian dari hasil analisis dengan program Exel dilanjutkan pengolahan data secara statistik dengan menggunakan program SPSS.

\section{Analisa Persamaan Regresi}

Dengan menggunakan program SPSS diketahui variabel tidak bebasnya adalah skala numerik yang diperoleh melalui transformasi logit biner pada probabilitas masing-masing point rating dan variabel bebasnya adalah $\mathrm{c}=$ biaya perjalanan dan $\mathrm{t}=$ waktu perjalanan.

\section{Menentukan nilai koefisien determinasi}

Tabel 6. Koefisien determinasi untuk pengguna moda mikrolet dan sepeda motor

\begin{tabular}{l|c|r|r|r}
\hline Model & $\mathrm{R}$ & \multicolumn{1}{|c|}{ R Square } & Adjusted R Square & Std. Error of the Estimate \\
\hline 1 & $.469^{\mathrm{a}}$ & .220 & .219 & 1.5858786 \\
\hline
\end{tabular}

Predic: (Constant), TIME, COST , Dependent

Variable: skala num

Tabel 6 tersebut menunjukkan bahwa nilai koefesien determinasi ( $\left.\mathrm{R}_{\text {square }}\right)$ diperoleh sebesar 0,22 yang dapat diartikan bahwa $22 \%$ pemilihan moda sepeda motor dan mikrolet dipengaruhi oleh biaya dan waktu perjalanannya, sedangkan sisanya dipengaruhi oleh sebab-sebab lain yang tidak diteliti.

\section{Menentukan nilai korelasi}

Tabel 7. Nilai korelasi untuk biaya dan waktu perjalanan

\begin{tabular}{l|l|r|r|r}
\hline \multirow{2}{*}{ SKALA_NUMERIK } & & SKALA NUMERIK & \multicolumn{1}{c}{ COST } & \multicolumn{1}{c}{ TIME } \\
\cline { 2 - 5 } & Pearson Correlation & 1 & $-.363^{* * *}$ & $-.204^{* *}$ \\
\cline { 2 - 5 } & Sig. (2-tailed) & & .000 & .000 \\
\cline { 2 - 5 } & $\mathrm{N}$ & 1220 & 1220 & 1220 \\
\hline \multirow{2}{*}{ COST } & Pearson Correlation & $-.363^{* *}$ & 1 & $-.236^{* *}$ \\
\cline { 2 - 5 } & Sig. (2-tailed) & .000 & .000 \\
\cline { 2 - 5 } & $\mathrm{N}$ & 1220 & 1220 & 1220 \\
\hline \multirow{2}{*}{ TIME } & Pearson Correlation & $-.204^{* *}$ & $-.236^{* * *}$ & 1 \\
\cline { 2 - 5 } & Sig. (2-tailed) & .000 & .000 & 1220 \\
\cline { 2 - 5 } & $\mathrm{N}$ & 1220 & 1220 & 120 \\
& & & & \\
\end{tabular}

**. Correlation is significant at the 0.01 level (2-tailed).

\section{Ujif}

Tabel 8. Uji Statistik F

\begin{tabular}{l|l|r|r|r|r|r}
\hline \multicolumn{2}{l|}{ Model } & Sum of Squares & Df & Mean Square & F & Sig. \\
\hline \multirow{2}{*}{1} & Regression & 864.755 & 2 & 432.378 & 171.919 & $.000^{\mathrm{a}}$ \\
\cline { 2 - 7 } & Residual & 3060.768 & 1217 & 2.515 & & \\
\cline { 2 - 7 } & Total & 3925.523 & 1219 & & & \\
\hline
\end{tabular}

Predictors: (Constant), TIME, COST

Dependent Variable: SKALA_NUMERIK

Analiasa Probabilitas Pemilihan Moda Transportasi Antara Sepeda Motor Dengan Angkutan Umum di Kota Lhokseumawe - HermanFithra, Burhanuddin, Fauzan, Cut Ayu Lizar 
Hasil pengujian hipotesis F menunjukkan hasil perhitungan SPSS dengan nilai $F_{\text {hitung }}$ sebesar 171,919 sedangkan nilai $F_{\text {tabel }}$ diperoleh dari microsoft exel dengan cara pada cell kosong ketik $=\operatorname{FINV}(0.05,1217,1219)$, derajat kebebasannya adalah: $(\mathrm{n}-\mathrm{k}-1)=(1220-2-1)=1217$, dimana $\mathrm{n}$ adalah jumlah sampel dan $\mathrm{k}$ adalah jumlah variabel independen, dan $(\mathrm{n}-1)=(1220-1)=1219$. Taraf signifikansi yang digunakan sebesar 5\% memakai uji dua arah diperoleh nilai $\mathrm{F}_{0,05 ; 1217 ; 1219}=1,098$.

Nilai koefisien regresi

Tabel 9. Nilai koefisien regresi untuk pemilihan moda sepeda motor dan mikrolet

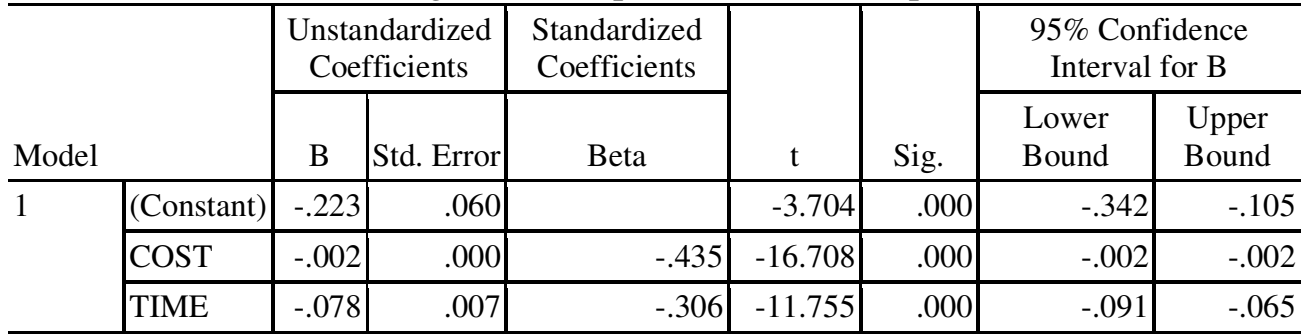

Dependent Variable: SKALA NUMERIK

Sehingga model pemilihan moda yang terbaik adalah:

$\left(\mathrm{U}_{s p}-\mathrm{U}_{m k}\right)=-0,223-0,002 \mathrm{C}-0,078 \mathrm{~T}$

\section{Analisis Model Pemilihan Moda}

Persamaan model pemilihan moda hasil analisa adalah sebagi berikut:

$\left(\mathrm{U}_{s p}-\mathrm{U}_{m k}\right)=-0,223-0,002 \mathrm{C}-0,078 \mathrm{~T}$

Dengan:

$\mathrm{U}_{\mathrm{sp}}-\mathrm{U}_{\mathrm{mk}} \quad=$ Utilitas moda sepeda motor dengan mikrolet

$\mathrm{C}=$ Selisih biaya perjalanan antara sepeda motor dan mikrolet

$\mathrm{T}=$ Selisih waktu tempuh perjalanan antara sepeda motor dan mikrolet

Hasil uji f memenuhi yang disyaratkan, sehingga dapat diambil kesimpulan bahwa seluruh atribut yang dipertimbangkan yaitu biay dan waktu perjalanan berpengaruh terhadap persamaan utilitas moda. Berdasarkan tanda pada koefisien persamaan diatas dapat dijelaskan sebagai berikut:

1. Konstanta sebesar $-0,223$ menyatakan bahwa jika tidak ada selisih biaya Cost (C) dan waktu perjalanan (T) maka selisih utilitas adalah -0,223.

2. Koefisien regresi cost (C) sebesar -0,002, menyatakan bahwa setiap penambahan sebesar 1 maka akan ada penurunan selisih utilitas sebesar -0,002 (karena -).

3. Koefisien regresi time (T) sebesar $-0,078$, menyatakan bahwa setiap penambahan sebesar satu maka akan ada penurunan selisih utilitas sebesar 0,078 (karena -).

\section{Probabilitas Pemilihan Moda}

Data eksisting :

- Biaya perjalanan Sepeda Motor : : Rp. 1.750,-

- Biaya perjalanan Mikrolet : Rp. 2.000,-

- Waktu perjalanan Sepeda Motor : 15 Menit

- Waktu Perjalanan Mikrolet : 25 Menit 
Selisih biaya perjalanan antara Sepeda Motor - Mikrolet :

$=$ Rp. $1.750-$ Rp. $2.000=-$ Rp. 250

$>$ Selisih waktu perjalanan antara Sepeda Motor - Mikrolet :

$=15$ Menit -25 Menit $=-10$ Menit

$>$ Utilitas / Nilai Kepuasan Responden dalam memilih moda :

$\left(\mathrm{U}_{s p}-\mathrm{U}_{m k}\right)=-0,223-0,002 \mathrm{C}-0,078 \mathrm{~T}$

Sehingga

$\left(\mathrm{U}_{s p}-\mathrm{U}_{m k}\right)=-0,223-0,002(-250)-0,078(-10)=1,057$

Probabiltitas / Peluang suatu Moda dapat terpilih:

- Sepeda Motor

$$
\mathrm{P}_{\mathrm{sp}}=\frac{\exp ^{(U \text { mikrolet-U Sepeda Motor })}}{1+\exp ^{(\text {mikrolet-U Sepeda Motor })}}=\frac{\exp ^{2.0 \mathrm{~s}}}{1+\operatorname{mx} \mathrm{p}^{1057}}=0,742=74,2 \%
$$

- Mikrolet

$$
\mathrm{Pm}=1-\mathrm{P}_{\mathrm{sp}}=1-0,742=0,258=25,8 \%
$$

\section{Sensitivitas model}

Sensivitas model dimaksudkan untuk memahami perubahan nilai probabilitas pemilihan moda salah satu sepeda motor atau mikrolet seandainya terjadi perubahan biaya untuk atribut (Cost) dan perubahan waktu untuk atribut (Time).

Tabel 10. Sensitivitas probabilitas pemilhan moda dengan utilitas terhadap

\begin{tabular}{|c|c|c|c|c|c|c|c|}
\hline Pilihan & $\begin{array}{c}\text { Biaya } \\
\text { Perjalanan } \\
\text { SM } \\
(\mathrm{Rp}) \\
\end{array}$ & $\begin{array}{c}\text { Biaya } \\
\text { Perjalanan } \\
\text { MK } \\
(\mathrm{Rp})\end{array}$ & $\begin{array}{c}\text { Selisih } \\
\text { Biaya } \\
\text { Perjalanan } \\
\text { SM - MK } \\
\text { (Rp) } \\
\end{array}$ & $\begin{array}{c}\text { Selisih Waktu } \\
\text { Perjalanan } \\
\text { SM - MK } \\
\text { sebenarnya } \\
\text { (menit) }\end{array}$ & $\begin{array}{l}\text { U ( SM } \\
-\mathrm{MK})\end{array}$ & $\begin{array}{c}\mathrm{Pr} \\
\mathrm{SM}\end{array}$ & $\begin{array}{c}\mathrm{Pr} \\
\mathrm{MK}\end{array}$ \\
\hline $1 \mathrm{a}$ & 1.750 & 1.000 & 750 & -10 & $-0,943$ & 0,280 & 0,720 \\
\hline $\mathrm{b}$ & 1.750 & 1.500 & 250 & -10 & 0,057 & 0,514 & 0,486 \\
\hline $\mathrm{c}$ & 2.000 & 2.000 & 0 & -10 & 0,557 & 0,636 & 0,364 \\
\hline $\mathrm{d}$ & 1.750 & 2.000 & -250 & -10 & 1,057 & 0,742 & 0,258 \\
\hline $\mathrm{e}$ & 1.750 & 2.500 & -750 & -10 & 2,057 & 0,887 & 0,113 \\
\hline
\end{tabular}
perubahan biaya (waktu perjalanan tetap)

Dengan hanya memperlihatkan perubahan selisih biaya, untuk kompetisi pemilihan moda antara sepeda motor dan mikrolet dapat dijelaskan bahwa probabilitas memilih sepeda motor akan lebih besar dari probabilitas memilih mikrolet bila selisih biaya sepeda motor dan mikrolet lebih kecil dari Rp. 250,-.

Tabel 11. sensitivitas probabilitas pemilhan moda dengan utilitas terhadap perubahan waktu (biaya perjalanan tetap)

\begin{tabular}{c|c|c|c|c|c|c|c}
\hline Pilihan & $\begin{array}{c}\text { Waktu } \\
\text { Tempuh } \\
\text { SM } \\
(\text { Rp) }\end{array}$ & $\begin{array}{c}\text { Waktu } \\
\text { Tempuh } \\
\text { MK } \\
(\text { Rp) }\end{array}$ & $\begin{array}{c}\text { Selisih Biaya } \\
\text { Perjalanan SM-MK } \\
\text { sebenarnya } \\
\text { (Rp) }\end{array}$ & $\begin{array}{c}\text { Selisih } \\
\text { Waktu } \\
\text { Perjalanan } \\
\text { SM-MK } \\
\text { (menit) }\end{array}$ & $\begin{array}{c}\text { U ( SM } \\
- \text { MK) }\end{array}$ & $\begin{array}{c}\text { Pr } \\
\text { SM }\end{array}$ & $\begin{array}{c}\text { Pr } \\
\text { MK }\end{array}$ \\
\hline 2a & 15 Menit & 20 Menit & -250 & -5 & 0,667 & 0,661 & 0,339 \\
\hline $\mathrm{b}$ & 15 Menit & 25 Menit & -250 & -10 & 1,057 & 0,742 & 0,258 \\
\hline $\mathrm{c}$ & 15 Menit & 15 Menit & -250 & 0 & 0,277 & 0,569 & 0,431 \\
\hline $\mathrm{d}$ & 20 Menit & 15 Menit & -250 & 5 & $-0,113$ & 0,472 & 0,528 \\
\hline $\mathrm{e}$ & 25 Menit & 15 Menit & -250 & 10 & $-0,503$ & 0,377 & 0,623 \\
\hline
\end{tabular}


Dengan hanya memperhatikan perubahan selisih waktu tempuh perjalanan, dapat dijelaskan bahwa probabilitas memilih sepeda motor akan lebih besar dari probabilitas memilih mikrolet bila selisih waktu tempuh perjalanan $<$ dari 0

\section{Kesimpulan dan Saran}

5.1 Kesimpulan

1. Dari hasil penelitian, responden lebih memilih sepeda motor sebagai moda untuk melakukan perjalanannya dari pada mikrolet.

2. Sepeda motor lebih dipilih pria dengan pertimbangan alasan waktu, sedangkan wanita lebih memilih mikrolet dengan pertimbangan alasan biaya.

3. Pada saat kondisi atribut sama dengan nol didapatkan nilai probabilitas sepeda motor lebih besar dari probabilitas mikrolet $\left(\operatorname{Pr}_{\text {Sepeda Motor }}>\operatorname{Pr}_{\text {mikrolet }}\right.$ untuk atribut cost dan time.

4. Model yang diperoleh dari analisa regresi terhadap semua data mempunyai harga $\mathrm{R}^{2}$ yang paling tinggi yakni 0,22 atau $22 \%$ yaitu pengaruh dari kedua faktor yang dipertimbangkan dan sisanya $78 \%$ dipengaruhi oleh atribut yang belum dipertimbangkan, misalnya faktor kenyamanan dan keamanan.

\subsection{Saran}

1. Perancangan kuesioner dan sensitivitas atribut perjalanan diusahakan sesederhana mungkin agar responden cepat mengerti dalam pengisiannya dan pertanyaan dan option jawaban diusahakan mewakili keadaan moda yang sebenarnya dan penggambaran moda lewat sensitivitas agar bisa lebih dimengerti.

2. Kesulitan dijumpai pada saat survei lapangan, karena berhubungan dengan banyak orang dengan berbagai kondisi. Oleh karena itu, ada baiknya diperlukan beberapa tenaga surveyor untuk bisa membantu pengumpulan data.

\section{Daftar Kepustakaan}

1. Afandi, Achmad T. 2010, Model Pemilihan Moda Angkutan Penumpang Kapal Feri (PT.ASDP) \& Kapal Cepat (SWASTA) Rute Sibolga - Gunung Sitoli (Dengan Metode Stated Preference), http://www.google.com, Diunduh tanggal 1 Desember 2012

2. Irianto, Agus. 2004, Statistik Konsep Dasar \& Aplikasinya,

3. Prenada, 2004. Ghozali Imam, 2005, Aplikasi Analisis Multivariated Dengan Prigram SPSS, Universitas Diponogoro, Semarang

4. Miro, Fidel. 2002, Perencanaan Transportasi, Erlangga, Yakarta.

5. Mutiara, K Erna. 2004, Statistical Product and Service Solution, Alfabetha, Bandung.

6. Sugiyono. 2012, Statistika Untuk Penelitian, Alfabetha, Bandung.

7. Tamin, O.Z. 2000, Perencanaan dan Permodelan Transportasi, Edisi ke-2, ITB, Bandung.

8. Tamin, 2008, Perencanaan, Premodelan, dan Rekayasa Transportasi, ITB, Bandung.

9. Warpani, Suwardjoko P. Pengelolaan Lalu Lintas dan Angkutan Jalan, ITB, Bandung.

10. Walpole, Ronald E. Dan Myers, Raymond H., 1986. Ilmu Peluang dan Statistika untuk Insinyur dan Ilmuan. Penerbit ITB, Bandung. 